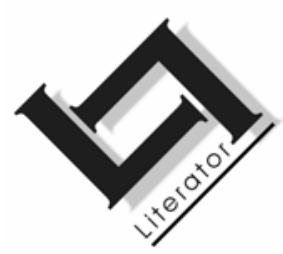

\title{
Jong lesers se identifisering met karakters: skryfteorie en -praktyk
}

\author{
Franci Greyling \\ Vakgroep Skryfkuns \\ Skool vir Tale \\ Potchefstroomkampus \\ Noordwes-Universiteit \\ POTCHEFSTROOM \\ E-pos: sktsfg@puk.ac.za
}

\begin{abstract}
Young readers' identification with characters: the theory and practice of creative writing

It is generally acknowledged that reader identification with characters contributes to readers' involvement in the text and the subsequent pleasure derived from reading stories. It seems that establishing a relationship with the implied reader of the text comes naturally for successful authors. There is, however, a lack of coherent theory on reader identification with characters which can be used in the teaching of creative writing. This article combines insights gained from various disciplines in order to develop a coherent theory of the phenomenon of reader identification. Of special interest are the results of reader-response research regarding the relation between individuals' development phase and identification with characters. Some of the possibilities which the writer can utilise to establish a relationship with the reader and influence the nature of reader identification with characters are the choice of characters and their depiction in the text, the narrative strategy and the use of viewpoint.
\end{abstract}

\section{Opsomming}

Jong lesers se identifisering met karakters: skryfteorie en -praktyk

Die betrokkenheid van die leser by 'n verhaal word allerweë as belangrik beskou, veral ten opsigte van jong lesers. Dit word 
algemeen aanvaar dat identifisering met 'n karakter tot leserbetrokkenheid en gepaardgaande leesgenot bydra. Dit wil voorkom dat suksesvolle skrywers natuurlikerwys daarin slaag om 'n verhouding met die implisiete leser in die teks te skep. Daar is egter 'n behoefte aan 'n samehangende teorie oor leseridentifisering met karakters, wat in die onderrig van kreatiewe skryf gebruik kan word. In hierdie artikel word insigte vanuit verskeie dissiplines gekombineer ten einde 'n samehangende teorie vir die verskynsel van leseridentifisering daar te stel. Wat veral van belang is, is die resultate van leserresponsstudies en die individu se ontwikkelingsfase en identifisering met karakters. Sommige van die moontlikhede wat die skrywer kan gebruik om 'n verhouding met die leser te skep en die aard van leseridentifisering met karakters te beïnvloed is die keuse en voorstelling van karakters, vertelstrategie en perspektief.

\section{Inleiding}

Die betrokkenheid van die leser by 'n verhaal word allerweë as belangrik beskou. Dit is egter veral wanneer jong lesers ter sprake is, dat leserbetrokkenheid ' $n$ primêre verwagting is waaraan die verhaal, en dus die skrywer, moet voldoen.

Dit word algemeen aanvaar dat identifisering met 'n karakter grootliks tot sodanige leserbetrokkenheid en gepaardgaande leesgenot bydra (Harding, 1977:67; Whitehead et al., 1978:208; Card, 1988:163; Van Assche, 1989:63). Tóg is identifisering met karakters 'n tema wat min aandag in die literatuur geniet. Alhoewel die konsep binne die literêre teorie gebruik word, word dit selde diepgaande bestudeer. Bestaande kennis oor identifisering kom hoofsaaklik uit literêr-teoretiese benaderings soos resepsie-estetika (Ghesquiere, 1982; McGilles, 1996) en uitvloeisels daarvan, soos die literatuurpsigologie en ideologiekritiek, waaronder leesbelangstelling (Whitehead et al.; 1978), leserrespons (Schram, 1985; Applebee, 1978; Protherough, 1983a; 1983b) en leesbegeleiding (Chambers, 1991). In die skryfkuns is insigte oor identifisering beperk tot skryfhandleidings oor karakters (Card, 1988) en kinderlektuur (Aiken, 1982; Woolley, 1990) en opmerkings van skrywers vanuit die skryfpraktyk. Empiriese navorsing wat in leserresponsstudies oor identifisering gedoen word, word selde met literêre en skryfteorie in verband gebring. Insigte oor identifisering is dus in ' $n$ groot mate losstaande inligting binne die verskillende terreine.

Hierdie leemte aan samehangende inligting oor leseridentifisering met karakters, asook die behoeftes aan voortgesette ontwikkeling 
van die skryfteorie en praktiese begeleiding ten opsigte van die skryf van kinder- en jeugliteratuur, bevestig die belangrikheid van navorsing oor dié onderwerp.

'n Beter begrip van identifisering en die werking daarvan in die teks kan waardevol wees vir die skrywer, aanbieders van skryfkursusse en redigeerders van kinder- en jeugverhale.

In hierdie artikel word verskeie invalshoeke op identifisering behandel en verbande daartussen word gelê om sodoende 'n bydrae te lewer tot ' $n$ beter begrip van die verskynsel van identifisering met besondere toepassing op die teorie en praktyk van skryf oor die algemeen en kinder- en jeugliteratuur in die besonder.

\section{Probleemstelling, doel, metodes en strategie}

'n Skrywer gee deur die keuses wat in 'n teks gemaak word, blyke van die leser wat hy of sy in gedagte het, die verhouding wat met dié implisiete leser opgebou moet word, en hoe die teks gelees en verstaan behoort te word (Chambers, 1991:92). Die bedrewe skrywer het waarskynlik 'n intuïtiewe aanvoeling vir die leser en vir die wyses waarop ' $n$ verhouding met die leser verkry word, en dus ook hoe identifisering met karakters bewerkstellig kan word. Dit behoort egter moontlik te wees om deur die bestudering van teoretiese insigte oor identifisering tot 'n beter begrip te kan kom van die aard van leseridentifisering met karakters en hoe dit skryfmatig toegepas kan word. Die doel van hierdie artikel is om die verskillende teoretiese aspekte sodanig met mekaar in verband te bring, sodat dit kan bydra tot insig in identifisering met die oog op die ontwikkeling van die skryfkunsteorie en toepassingsmoontlikhede in die skryfpraktyk.

Die navorsingsmetode behels 'n literatuurstudie vanuit verskeie dissiplines. Benewens literêre teorie en die skryfkunsteorie, word ook insigte vanuit die psigologie, opvoedkunde, leserkunde en skryfpraktyk betrek. Resultate van empiriese studies word met die skryfteorie en skryfpraktyk in verband gebring.

Ten einde 'n beter begrip te hê van identifisering en die werking daarvan in literatuur, hanteer die artikel die verskynsel vanuit verskeie invalshoeke. Vir die begripsverklaring word literêre sienings oor identifisering en insigte uit die sosiale wetenskappe betrek. Vervolgens word identifisering in terme van die leser beskou, insluitend aspekte soos die funksie en werking van literatuur en die leesproses. Hier dra resultate van resepsie-estetika tot waardevolle 
insigte by. Die verworwe insigte word met beginsels uit die literêre teorie en skryfteoretiese beginsels gekombineer en op die keuse, skep en voorstelling van karakters van toepassing gemaak.

\section{Konseptuele raamwerk}

Verwysings na identifisering met karakters kom gereeld in skryfhandleidings, boekresensies en boekkeurings voor. Die algemene gebruik van dié uitdrukking bring egter mee dat dit selde gedefinieer word en dat uiteenlopende betekenisse daaraan geheg word.

Die verwarring rondom die begrip identifisering kan volgens Schram (1985:180) toegeskryf word aan die uiteenlopende beskouings vanuit die psigologie en die literatuurwetenskap. Dit is waarskynlik weens die assosiasie met die psigologie (veral die psigoanalise) dat die term in 'n mate in onguns verval het en vermy of vervang word met verwante begrippe soos inlewing, meelewing, betrokkenheid, simpatie, empatie en omgee vir 'n karakter (kyk ook Coplan, 2004:147).

In die literatuurwetenskap kan drie hoofrigtings ten opsigte van identifisering aangedui word, naamlik dié met 'n sterk psigoanalitiese onderbou, dié wat op sosiale leerteorieë steun en selfstandige denkrigtings. Die grense tussen hierdie rigtings is diffuus. Dit bring mee dat dit nie altyd van mekaar onderskei kan word nie en 'n basisopvatting ook nie noodwendig aantoonbaar is nie (Schram, 1985:194, 197).

In kinder- en jeugliteratuur is die teorie van Harding, wat sterk steun op die psigologiese posisie van die toeskouer (onlooker), prominent. Volgens Harding (1977:58-72) behels die lees van fiksie twee verwante prosesse wat met dié van toeskouer-wees ooreenstem, naamlik waarneming (terloops of gefassineer) en evaluering. Die mate waarin 'n leser as toeskouer betrokke is, kan wissel na gelang van belangstelling en is ook sterk afhanklik van die leser se vermoë om hom- of haarself in 'n situasie te plaas - dus van die leser se verbeelding. As gevolg van die kompleksiteit van die verhouding tussen leser en teks, vind Harding (1977:67) 'n enkelterm identifisering - ontoereikend en onderskei hy vier verskillende prosesse, te wete herkenning, bewondering, nabootsing en empatie.

Ná 'n lang beredenering van Harding se sienswyse, besluit Whitehead et al. (1978:219) dat dit nie die volle effek van identifisering verduidelik nie. Hulle gee egter toe dat die leesproses 
en leesgenot van twee nóú verweefde prosesse afhanklik is, naamlik dié van identifisering en distansiëring.

In 'n meer genuanseerde model onderskei Jauss (1977:212-258) tussen verskillende vorms van identifisering, te wete assosiatiewe, bewonderende, simpatieke, katarsiese en ironiese identifisering. Hierdie vorms kom in verskillende kombinasies en grade voor en hou ook verband met die individuele resepsieproses. Hiermee saam bepaal die verhaalsoort, die aard van die karakter (held) en die diskoers in 'n hoë mate die soort identifisering wat plaasvind en die leesresultaat (positief of negatief) wat dit tot gevolg het. Navorsers poog steeds om die nuanses van leserbetrokkenheid te beskryf. Coplan (2004:17) gebruik die psigologie as basis om aan te toon dat die gebruik van die term identifisering in werklikheid na verskillende psigologiese prosesse verwys, naamlik empatie, emosionele aansteking en simpatie. Hierdie onderskeid kom grootliks neer op die aard en intensiteit van leserbetrokkenheid by karakters.

As gevolg van dié verskeidenheid sienings is dit moeilik om 'n algemene definisie vir identifisering te kry. Die omskrywing waarop hoofsaaklik gesteun word, is dié van Van Assche (1989:62) wat identifisering beskryf as 'n grotendeels onbewuste proses waardeur die leser hom- of haarself geheel of gedeeltelik met die karakters in 'n teks, hul gedagtes, gevoelens en belewenisse en daarmee gepaardgaande situasies en probleme vereenselwig. Dié omskrywing word verkies aangesien dit 'n nugter beskouing is wat vir sowel verskillende grade as vorms van identifisering voorsiening maak. Dit wys ook op die aard daarvan en die resultaat van leserbetrokkenheid by die werk as geheel.

Soos reeds aangetoon, is die identifiseringsproses verweef met die teenstellende tendens van distansiëring (Schram, 1985:199; Van Assche, 1989:62). Hierdie teenpole, wat in beginsel neerkom op 'n onderskeid tussen die affektiewe en kognitiewe aspekte van die leesproses, word op velerlei wyses in die literatuur beskryf. Applebee (1978:124) verdeel kenmerkende reaksies in subjektiewe en objektiewe response, Harding (1962:136) onderskei tussen deelnemer en toeskouer, en Whitehead et al. (1978:225) beklemtoon dat sowel identifisering as evaluering noodsaaklik is vir die beskrywing van die leesproses. Coplan (2004:148) wat die term empatiese betrokkenheid verkies, verwys na die self-anderonderskeid wat ' $n$ leser in staat stel om ten diepste betrokke te raak by karakters se ervarings en terselfdertyd sy eie denke, emosies en begeertes te behou. 
Die balans tussen identifisering en distansiëring (toeskouer- en deelnemerwees) kan in die loop van die leesproses wissel. Volgens Chorus (1991:38) is die leser aanvanklik toeskouer, maar word deelnemer wanneer hy/sy deur die gebeure meegevoer word. Die kognitiewe proses van evaluasie en terugkyk na 'n verhaal, bring weer afstand mee (Chorus, 1991:38).

Benewens 'n voortdurende wisselwerking in die leesproses tussen identifisering en distansiëring, dra die teks as geheel ook by tot die aard en omvang van leserbetrokkenheid. Die estetiese afstand tussen teks en leser bepaal hoe maklik of moeilik 'n verhaal gelees word (Schram, 1985:206). Triviale werke waarin daar weinig afstand tussen leser of leserverwagtinge en die karakter is, moedig identifisering aan. Hierteenoor dra vernuwing of literariteit tot distansiëring by. 'n Verhaal kan dus só aangebied word dat die deelnemers- óf toeskouerrol aangemoedig word.

Vervolgens word die jong leser se identifisering met karakters van nader beskou.

\section{Die jong leser en identifisering met karakters}

\subsection{Die funksie en werking van literatuur en die effek van identifisering}

Wanneer identifisering bespreek word, kom die funksie en werking van literatuur vanselfsprekend aan die bod. Volgens Ghesquiere (1982:118) verwys die funksie van literatuur na die doel van die teks en die waarskynlike (uit)werking daarvan. Werking behels die effek daarvan op die leser - dus die wyse waarop die vermeende doelstelling wel bereik word. Alhoewel die beïnvloedingsmoontlikhede van literatuur reeds sedert Plato en Aristoteles aanvaar word (Culp, 1985:31), is dit ten opsigte van kinder- en jeugliteratuur veel prominenter as wat by literatuur vir volwassenes die geval is. Dit is grootliks toe te skryf aan die feit dat 'n mens in hierdie geval met (ontvanklike) kinders te doen het en ook by implikasie, met die opvoeding van die kind.

Ten opsigte van die funksie van literatuur onderskei Ghesquiere (1982:118) tussen opvoedkundige, psigologiese, maatskaplike, intellektuele en estetiese funksies. Dit is veral eersgenoemde drie wat op identifisering betrekking het. Alle kinder- en jeugliteratuur vervul volgens Ghesquiere (1982:119) 'n opvoedingsfunksie deurdat dit binne een of ander opvoedingsmodel pas en die ontplooiing van jeugdiges op die een of ander wyse wil bevorder. Argumente vír en 
téén identifisering kan dikwels na die opvoedingsfunksie teruggevoer word en betrek ook die ander funksies van identifisering - dit is veral die geval ten opsigte van die psigologiese funksie en verbandhoudende vormende en ontspannende funksies. Die vormende funksie het te make met die persoonsontwikkeling van die individu, en betrek aspekte soos die vorming van 'n eie identiteit, begrip vir ander en insig in die self en die situasie. Die veronderstelling is dat die jeugdige deur inlewing in die ander se omstandighede 'n groter gevoeligheid vir die verskille tussen mense ontwikkel, terwyl herkenning tot selfinsig bydra (vgl. Ghesquiere, 1982:120; Tucker, 1981:181; Stephens, 1992:81; Hancock, $1993: 42$ en Van der Westhuizen, 1997:314). Biblioterapie steun sterk op die vormende funksie van literatuur. Die ontspannende funksie van literatuur wat met die emosionele bevrediging in die leeservaring verband hou, word ook dikwels met die leser se identifisering met karakters verbind (Whitehead et al., 1978:22). Die maatskaplike funksie verwys na die sosialiserende funksie van literatuur, wanneer die individu deur literatuur kennis en vaardighede verwerf om aan 'n sosiale of kultuurgroep deel te neem (Hynds, 1985:32).

Die aanname dat lesers wel deur hul leesstof beïnvloed word, is onderliggend aan heelwat sienings oor kinder- en jeugliteratuur. Die oortuiging word dikwels uitgespreek dat kinders, vanweë hul ontwikkelingsfase en die intensiteit waarmee gelees word, méér as volwassenes deur leesstof beïnvloed kan word (Lohann, 1986:50). Verskeie effekte van lees kan aangetoon word. Andringa (2004:220) onderskei byvoorbeeld tussen direkte emosionele effekte gedurende en ná 'n leeservaring, eksterne effekte op gedrag, kognitiewe effek op idees en besinning, en effekte op die leser se lewe en lewensomstandighede. Alhoewel die mate waarin die leser deur leesstof beïnvloed word, asook die blywendheid van die effek, toenemend bevraagteken word (Ghesquiere, 1982:128-131), suggereer navorsing na identifiseringstendense in leesoutobiografieë dat individuele lesers wel beïnvloed word deur hul leeservaring en identifiseringspatrone (Andringa, 2004:216). Die werking van literatuur, naamlik die invloed daarvan op die kennis, insig en gedrag van die individu (Ghesquiere, 1982:129) kan egter nie met sekerheid bepaal word nie. Veranderlikes wat die werking van die verhaal beïnvloed, soos die individuele leser, spesifieke leeservaring, die teks, leessituasie en geloofwaardigheid van die skrywer (Ghesquiere, 1982:131) is ook aspekte wat ten opsigte van identifisering met karakters 'n belangrike rol speel. 
In aansluiting by die voorafgaande onderskei Schram (1985:212 e.v.) vier effekte van identifisering, naamlik opwekking van gevoelens, opwekking van verlangens, kognitiewe effekte en betekenistoekenning:

- Wanneer die leser met 'n karakter identifiseer, word gevoelens ten opsigte van die karakter opgewek. Dit is veral medelye en bewondering wat gereeld in kombinasie met mekaar voorkom. Die leser openbaar die gevoelens teenoor die karakter, en beleef nie emosies soortgelyk as dié van die karakter nie (Schram, 1985:212). Hierdie idee kom ooreen met Coplan (2004:143-144) se definisie van empatie.

- Opwekking van verlangens of wensvervulling is ter sprake wanneer die leser graag die karakter se ervarings wil meemaak. Dit is ' $n$ komponent wat veral in die psigoanalise beklemtoon word (Schram, 1985:213). Na aanleiding van die werk van Schoenmakers en Vliet onderskei Andringa (2004:209-210) tussen wensidentifisering en gelykvormige identifisering en verdeel eersgenoemde verder in droom-wensidentifisering en rolmodelwensidentifisering. Wensvervulling figureer dikwels sterk in verhale wat deur jeugdiges verkies word (Whitehead et al., 1978:225). Jong lesers identifiseer graag met karakters in liefdesen avontuurverhale, omdat hul behoefte aan aanvaarding, erkenning en prestasie hierdeur bevredig word (De Beer, 1991:7). Deur identifisering met 'n superheld word die opwinding van gevaar gedeel sáám met die sekerheid van uiteindelike sukses (Tucker, 1981:169).

- Onder kognitiewe effekte van identifisering onderskei Schram (1985:212) onder andere tussen normbevestigende, -vormende en -deurbrekende funksies. Hierdie funksies toon sterk ooreenstemming met die maatskaplike funksies van literatuur. Hy toon aan dat identifisering met karakters in triviale tekste gewoonlik gepaard gaan met normbevestiging. Normvorming, wat sentraal in die psigologiese teorieë staan, hou veral verband met die sosialisering van die jeugdige. Normdeurbreking behels die opdoen van nuwe ervarings, kennis en begrip van 'n ander, asook vernuwing ten opsigte van bestaande kennis, norme en waardes. Deur identifisering met 'n karakter kan dié nuwe insig verwerf word (Schram, 1985:213).

- Betekenistoekenning en waardering: alhoewel dit wyd aanvaar word dat identifisering leesplesier en begrip bevorder, bevind Schram (1985) dat identifisering met karakters tot leesgenot bydra, maar nie dat dit noodwendig tot beter begrip bydra nie. 
Begrip vir ' $n$ karakter en die situasie (met ander woorde die leser se kennis en lewenservaring) beïnvloed wel die identifiseringsmoontlikhede met die karakter (Dijkstra et al., 1994:146).

Die werking van literatuur, en dus ook die aard en effek van leseridentifikasie met karakters, hou ook verband met die leesrespons en veral met die ontwikkelingsfase van die leser.

\subsection{Die verband tussen leser, leesrespons en identifisering met karakters}

Alhoewel die leesproses ' $n$ individuele ervaring is, bevind verskeie studies 'n samehang tussen die ontwikkelingsfase van die jeugdige en die leesrespons. 'n Begrip van karakters en karakteroptrede hou byvoorbeeld verband met die sosiaalkognitiewe begrip van die leser, en dié is afhanklik van die ontwikkelingsfase waarin die kind hom-/ haarself bevind. Soortgelyke tendense word ook met betrekking tot betrokkenheid by 'n storie en die identifisering met karakters gevind. Twee navorsers wie se werk op dié terrein wye erkenning geniet, is Applebee (1978) en Protherough (1983a; 1983b) wat albei gebruik maak van jong lesers se eie evaluering en reaksie op hul leeservaring.

Applebee (1978:88-89) onderskei, in 'n ondersoek na die kind se konsep en ervaring van stories, tussen die subjektiewe en objektiewe gevoelens oor 'n storie. 'n Objektiewe respons behels algemeen verifieerbare eienskappe soos detail van karakter en ruimte, of bespreking van die tema, struktuur of vertelperspektief (point of view). Subjektiewe respons is die persoonlike ervaring van die werk. Dit begin by die stimulus wat deur die werk verskaf word asook in konvensies van interpretasie, maar wissel na gelang van die leser se gemoedstoestand. Applebee (1978:88-89) gebruik Piaget se teorieë van intellektuele ontwikkeling as basis vir sy werk en vind 'n sterk verband tussen leesrespons en Piaget se indeling.

Samevattend stel Applebee (1978:123-125) die kenmerkende respons soos volg:

- In die pre-operasionele fase (2-6 jaar) vertel 'n kind bloot die storie of gedeeltes daarvan oor, terwyl integrasie met 'n persoonlike, subjektiewe respons ontbreek.

- Tydens die konkreet-operasionele stadium (7-11 jaar) verwerf die kind die vermoë tot opsomming en kategorisering. Subjektiewe ervaring word regstreeks met die werk self in verband gebring, deur byvoorbeeld aan te dui dat die verhaal snaaks of hartseer is. 
- In die eerste fase van die formeel-operasionele denke (12-15 jaar) begin lesers hul persoonlike, subjektiewe respons analiseer en raak hulle ook bewus van die onderskeid tussen subjektiewe en objektiewe reaksies. Die neiging is dan om subjektiewe reaksie in terme van identifisering of betrokkenheid te formuleer. In hierdie fase begin hulle ook na redes soek vir hul eie subjektiewe reaksie ten opsigte van objektiewe eienskappe van die werk.

- Die tweede fase van formeel-operasionele denke (16 tot volwassene) bring mee dat lesers veralgemenings oor die werk maak en abstrakte stellings oor die tema of boodskap formuleer. In hul subjektiewe, persoonlike reaksies fokus lesers op hulle eie individuele reaksie op die werk, byvoorbeeld die effek daarvan op 'n eie insig/siening.

Dit wil voorkom asof identifisering met die karakter veral in die formeel operasionele fase van belang is. Dit kan egter ' $n$ oorvereenvoudigde siening wees, soos Applebee (1978:112) tereg daarop wys:

Paradoxically, it is precisely when the reader begins to talk of 'identification' or 'engagement' that the experience becomes further distanced psychologically: the response has become indirect, mediated through the recognition that is only 'like I was there', whereas for the younger child it is directly and immediately exciting.

Die afleiding kan wel gemaak word dat die aard en omvang van identifisering saamhang met die ouderdom (ontwikkelingsfase) van die jong leser.

Soortgelyke waarnemings oor die verband tussen ouderdom en die leesproses word deur Protherough (1983a; 1983b) gemaak. Hy identifiseer die afstand tussen leser, karakter en gebeure as 'n sleutelfaktor in die leesproses. Hierdie afstand of betrokkenheid wissel van algehele verdieping in die storie tot relatiewe verwydering en kritiese lees, naamlik: (1) projeksie in die karakter; (2) projeksie in die situasie; (3) assosiasie tussen die boek en die leser; (4) die verwyderde toeskouer en (5) onbetrokke evaluering.

Alhoewel 'n regstreekse verband tussen ouderdom en leesresultaat nie bestaan nie, kan sekere tendense wel aangetoon word. Kinders van 11-12 jaar is veral geneig om wyses 1 en 2 te gebruik, terwyl wyses 4 en 5 deur ouer respondente (14 jaar en ouer) gebruik word. Die ouderdomsgroep 13-14 jaar kan in elk van die vyf kategorieë verteenwoordig wees. Die vermoë om van 'n volgende modus van 
lees gebruik te maak, beteken nie noodwendig dat die ander nie meer gebruik word nie, maar dat die leser dan meer leesmoontlikhede tot sy of haar beskikking het (Protherough, 1983a:21). Hierdie meerdere vermoë hou ook in dat 'n leser tydens die leesproses ten volle by 'n karakter of in die storie betrokke kan wees, maar daarná tot onbetrokke evaluering in staat is.

Die tendens van toenemende distansiëring word ook in ander leesresponsnavorsing aangetref (vgl. Beach \& Wendler, 1987; Emery \& Milhalevich, 1992).

Daar kan ook ' $\mathrm{n}$ verband tussen die aard van identifisering met karakters en die leser se ouderdom aangetoon word. In sy navorsing oor die leesproses van 11-16-jariges bevind Protherough (1983a:44-45) dat jonger lesers meer met uiterlike karakterhandeling identifiseer, terwyl ouer lesers ook tot empatiese en gevoelsmatige identifisering in staat is. Dié waarneming word ondersteun deur navorsing van Jose en Brewer (1984:911-924) wat ten opsigte van spanningsverhale bevind dat die jonger lesers in hulle groep (graad 2) nie die affektiewe proses van identifisering met 'n karakter en gepaardgaande spanningsbelewing benut nie. Hulle geniet bloot 'n verhaal as die karakter ooreenkoms met die self toon. Hierteenoor speel empatiese identifisering by graad 6-leerlinge 'n veel groter rol in spanningsbelewing. Lesers neig ook om hul selfkonsep in karakters te projekteer, wat sodoende tot identifisering met die karakter bydra. In hierdie verband vind Beach en Brunetti (1976:265) dat graad 10-lesers in 'n groter mate as eerstejaarstudente hul selfkonsep in karakters projekteer. Tucker (1981:180) oordeel dat adolessente lesers se behoefte aan identifisering verband hou met die lewensfase waarin hulle hulself bevind en die gepaardgaande onsekerheid oor hul eie identiteit. Geslagsverskille kan verder ook 'n rol speel ten opsigte van identifisering. Seuns sal waarskynlik langer met die uiterlike handeling identifiseer, terwyl meisies vroeër tot empatiese identifisering geneig is. Verskille in leesvoorkeure kan moontlik deels hierdeur verduidelik word.

In 'n ondersoek na identifiseringspatrone in leesoutobiografieë van volwasse studente wat deur Andringa (2004:227-230) onderneem is, word bogenoemde tendense grootliks bevestig en word 'n natuurlike verdeling tussen die leespatrone van kinders en adolessente uitgewys. Andringa onderskei tussen wensidentifisering en gelykvorminge (similarity) identifisering en vind belangrike tendense ten opsigte van hierdie twee wyses van identifisering. Wensidentifisering, waar 'n leser in die avontuurlike wêreld van helde en heldinne wil behoort en in die situasie, karakters of gebeure wil deel, 
is kenmerkend van die kindertyd. Tydens adolessensie vind ' $\mathrm{n}$ duidelike verskuiwing plaas en oorheers gelykvorminge identifisering. In dié fase word die aard van identifisering uitgebrei. Benewens identifisering met karakters sluit dit ook identifisering met abstrakte onderwerpe en temas in wat 'n rol in die leser se lewe kan speel of waarmee hy homself kan vereenselwig. Hierdie verandering in die aard van identifisering kan verband hou met die ontwikkeling van die denke oor die self en die verhouding met die wêreld (Andringa, 2004:227-230).

Andringa (2004:226-227) bevind verder 'n opvallende verskil tussen die geslagte ten opsigte van identifisering. Identifisering (veral gelykvormige identifisering) is aansienlik prominenter by vroulike respondente. Vroulike lesers neig om fiksie met die lewe te verbind, terwyl manlike lesers eerder beïndruk word deur ander, onbekende wêrelde (vgl. Jose, 1989.)

Benewens kenmerkende leesontwikkeling, het die leesstyl van 'n individu ook 'n invloed op die leesresultaat. Dillon (1982:77-88) onderskei drie basiese leesstyle, te wete die karakter-aksie-moraalstyl (Character Action Moral style), delf na geheime-styl (digger for secrets style) en die antropologiese styl. Die meeste lesers maak van die karakter-aksie-moraal-styl gebruik. In dié styl word die teks as uitbreiding van die werklikheid hanteer. Karakters word as werklike mense beskou, terwyl hul ervaring as dié van dié leser self herken en soos die eie verstaan en beskryf kan word. Hierdie leesstyl, wat hom veral tot identifisering leen (Dillon, 1982:83), is die vorm wat oorwegend deur kinders gebruik word -'n waarneming wat deur Applebee (1978:132-133) se navorsing ondersteun word.

Die doel waarmee 'n teks gelees word, die leesomstandighede en motivering, kan bepaal watter leesstyl gebruik word en wat die resultaat kan wees. Leesstrategieë waarin leesstof geëvalueer en 'n mening geformuleer moet word, soos wat in literatuuronderrig verwag kan word, vereis 'n groter mate van distansiëring. Culp $(1985: 34)$ bevind byvoorbeeld dat studente wel met karakters in voorgeskrewe werke identifiseer, maar tog in 'n mindere mate as dié wat vrywillig gelees word.

Wat ook van belang is, is die leesbegrip van 'n individu. Leesbegrip is onder meer afhanklik van lees- en lewenservaring - twee samehangende aspekte wat die moontlikheid tot identifisering ten nouste raak. Leeservaring, of die literêre verwagtingshorison, behels vorige leeservaring en kennis van die betrokke subgenre, terwyl lewenservaring onder meer 'n leser se persoonlike, sosiale en kulturele 
agtergrond, individuele ontwikkelingsfase, sosiaalkognitiewe begrip, rol-aannemingsvermoë, geneigdheid tot empatie, ervaringswêreld, mensekennis en persoonlikheid behels.

Vervolgens word die implikasies van leseridentifisering vir die skrywer en skryfpraktyk bespreek.

\section{Implikasies vir die skrywer en skryfpraktyk}

\subsection{Identifisering met karakters - aan- of ontmoediging?}

Identifisering met karakters in 'n verhaal word gewoonlik as een van die primêre eise vir 'n geslaagde kinder- en jeugverhaal gestel (Steenberg, 1988:170; De Beer, 1991:6-7; Woolley, 1990:41). Identifisering bied die leser die geleentheid om vryelik deur tyd en ruimte te beweeg, ' $n$ verskeidenheid rolle en ervarings te deel en die verbeeldingswêreld uit te brei (Tucker, 1981:187). Verder dra leseridentifisering met karakters by tot leesgenot en ' $n$ behoefte om die leeservaring te herhaal - hetsy om meer boeke van dieselfde skrywer te lees, of om ander boeke te lees. Uit afdeling 4 blyk dit dat die neiging tot identifisering integraal is aan die jong leser se leesproses en die betrokke ontwikkelingsfase. Identifisering met karakters toon verder 'n samehang met subgenres en vorm deel van leserverwagtings. Vir die gewenste effek word die volgende vereis: spanningsverhale - noue identifisering van die leser met die slagoffer (Tucker, 1981:39; Jose \& Brewer, 1984:911-924); komedie - 'n sekere afstand tussen karakter en toeskouer (Booth, 1961:331); en historiese verhale - identifisering met die protagonis en die veronderstelling dat mense, ten spyte van groot tydsverskille, soortgelyke emosies deel (Donelson \& Nilsen, 1989:170; Stephens, 1992:205).

Ten spyte van soveel aandrang op identifisering, is daar ook diegene wat hulle sterk uitspreek teen tekste en leesstrategieë wat identifisering aanmoedig (Nodelman, 1981:177-185). Ander navorsers stel juis tegnieke voor wat tot distansiëring bydra (Stephens, 1992:198).

Die klem op identifisering - hetsy deur die skrywer met die vestiging van die implisiete leser, of deur die voorkeur en leesstrategie van die jeugdige - lei, volgens Nodelman (1981:181), tot 'n verskraalde leeservaring. Indien lesers slegs 'n verhaal geniet wanneer hulle maklik met die karakters kan identifiseer, is 'n vereenvoudigde werklikheid uitgebeeld, en lesers word op dié manier van alternatiewe ervarings ontneem. Nodelman (1981:184) se siening dat 
verhale wat identifisering verwag tot 'n verskraalde ervaring kan lei, word deur Stephens gedeel. Stephens (1992:68) is besorg oor moontlike intellektuele manipulering waaraan 'n leser in die subjekposisie aan identifisering blootgestel word. Hy dui strategieë aan waarmee distansiëring in die teks bevorder kan word. Karakters is draers van die waardes van die verhaal (Van der Westhuizen, 1997:82). Dit bring mee dat deur identifisering met die karakters die lesers ook sodoende (onbewus) in die verhaalvisie deel.

Uitgangspunte soos hierdie hou verband met die siening van die kind (die jong leser) en die funksie van kinder- en jeugboeke. Moet die skrywer van verhale vir jeugdiges identifisering met karakters aanmoedig of nie?

'n Skrywer wil graag 'n bepaalde effek met 'n verhaal en karakters bereik. Om hierin te kan slaag, moet 'n verhouding tussen die leser en teks (karakters) opgebou word. Indien die skrywer identifisering met 'n karakter wil bevorder, sal ander strategieë gevolg word as wanneer distansiëring belangrik is.

Alhoewel die gedagte om identifisering met die karakters te ontmoedig, vreemd mag voorkom, gebruik skrywers tog verskeie tegnieke om 'n karakterhiërargie te vestig. Die veronderstelling is dat identifisering grootliks met die sentrale karakter plaasvind. Navorsing suggereer dat identifisering met 'n protagonis ' $n$ natuurlike proses is en dat die leser 'n posisie binne die tyd-ruimtelike raamwerk van die narratief inneem wat op die posisie van die protagonis gebaseer is - met ander woorde, die fisiese perspektief van die karakter word gedeel (Coplan, 2004:142). Lesers kan egter op verskeie wyses by verskillende karakters betrokke wees - dié resultaat word grootliks deur die skrywer gerig. Sentrale karakters word op hierdie manier uitgelig en simpatie vir hulle verkry; pro- en antagoniste kom sodoende tot stand; 'n afkeer aan sekere karakters ontwikkel, ensovoorts. 'n Skrywer kan ook moontlik oordeel dat ondeurdagte identifisering met 'n sentrale karakter nie gewens is nie, en dat 'n mate van distansiëring met die sentrale karakter juis tot die doelstellings van die werk kan bydra.

Waar identifisering 'n natuurlike proses van leesontwikkeling is en bydra tot ' $n$ genotvolle leeservaring - veral vir die jong leser by wie wensvervullende (wensidentifisering) so belangrik is - is dit egter te betwyfel dat die deursnee leser 'n verhaal sal geniet waarin identifisering met die protagonis ontmoedig word. 
Met inagneming van die individuele leesrespons kan die skrywer deur die keuses wat hy of sy maak en die aanwending van verskeie tegnieke, die emosionele afstand (identifisering of distansiëring) tussen die leser en karakter beïnvloed. Hierdie moontlikhede word vervolgens ondersoek.

\subsection{Die keuse, skep en voorstelling van karakters}

Tydens die skeppingsproses neem die skrywer deurgaans besluite. Soos reeds aangedui behels hierdie (bewuste of onbewuste) besluite onder meer aspekte soos die bedoelde leser, die keuse van genre, tema, ensovoorts. Dié keuses beïnvloed weer die aanwending van die skeppingsmedium, -middele en -elemente. Die resultaat van die besluitneming (en die vakmanskap van die skrywer) bepaal hoe die leser die teks sal ontvang. Aangesien identifisering veral met die karakters in 'n verhaal verband hou, word dié skeppingselement vervolgens behandel deur aandag te gee aan die keuse, skep en voorstelling van karakters en die vertelproses.

\subsubsection{Die keuse van karakters - ooreenkomste tussen leser en karakter}

Die keuse van karakters, veral die hoofkarakter, is gewoonlik een van die belangrikste oorwegings vir 'n skrywer. Hoe belangrik is die ooreenkoms tussen karakters en die implisiete leser vir identifisering met die karakter?

Navorsing vanuit die psigologie wys daarop dat empatie (kognitief en affektief) geredeliker plaasvind waar daar 'n groter ooreenkoms tussen die kind en die ander is. Hierdie empatie wat emosies soos geluk, hartseer, vrees en woede insluit, kan egter ook 'n vorm van projeksie wees wanneer die eie gevoelens en denke aan die ander toegeskryf word (Shantz, 1975:19). Die identifiseringsproses in literatuur toon ooreenkomste hiermee. Verskeie navorsers vind dat 'n ooreenkoms tussen karakter en leser lei tot identifisering, begrip, genot en waardering van die teks en karakter (Jose \& Brewer, 1984; Schram, 1985; Jose, 1989). Lesers projekteer dikwels eie eienskappe in karakters (Shantz, 1975:19; Beach \& Brunetti, 1976:265) en begrip van sentrale karakters word sterk beïnvloed deur die persoonlikheid en selfkonsep van die leser (Kingston \& White, 1967:114).

Dit wil voorkom dat hoe meer die kinderleser en karakter se situasie ooreenstem, hoe groter die moontlikheid tot empatie is. Dié ooreenkomste kan ooglopend wees, soos byvoorbeeld geslag, 
ouderdom, ras en gedeelde leefwêreld, maar dit is nie noodwendig die geval nie (vgl. Greyling, 1999:243-251). Donelson en Nilson (1989:135) sowel as Whitehead et al. (1978:252) ag emosionele inhoud belangriker vir identifisering as omstandighede, lewenstyl of ervaring soortgelyk aan dié van die karakter. Instinktiewe bevrediging vind plaas wanneer die emosionele behoeftes, vrese en konflik wat kenmerkend van 'n leser se ouderdom en ontwikkelingsfase is, aangeroer word.

\subsection{Die skep, toerusting en voorstelling van die karakter}

In die proses om karakters te skep, rus die skrywer hulle toe met eienskappe vir 'n bepaalde rol. Die wyse waarop dié beplande karakter(s) in die teks voorgestel word en die wisselwerking met ander skeppingselemente (ruimte, tyd en gebeure) bepaal hoe die leser die karakter "herskep", asook die afstand wat die leser van die teks en die karakter ervaar.

Skryfhandleidings gee baie aandag aan die toerusting van karakters en die rol in die verhaalgebeure, asook die voorstelling van karakters. Hierdie inligting is meestal ongestruktureerd en gegrond op algemene waarnemings. Insigte van Van den Bergh (1981) en Bal (1986) kan bydra om dié aspek beter te begryp en te orden.

In 'n ondersoek na oorredingstegnieke in kortverhale, identifiseer Van den Bergh (1981:153-172) kenmerkende patrone wat hy aan die hand van die driehoeksverhouding, implisiete skrywer, werklike leser en karakters, kategoriseer. Ten opsigte van die verhouding tussen implisiete skrywer en karakter is betroubaarheid van toepassing; tussen leser en implisiete skrywer is dit geloofwaardigheid; en tussen leser en karakter is verwantskap relevant. Laasgenoemde het betrekking op die wyse waarop die karakter positief of negatief gekleur word, herkenbaar gemaak word, simpatie ontlok word en identifisering aangemoedig word - met ander woorde, hoe die estetiese afstand tussen leser en karakter gemanipuleer word. Wanneer 'n positiewe verhouding tussen leser en karakter geskep word, verklein die afstand en sodoende kan identifisering aangemoedig word. 'n Positiewe verhouding tussen leser en karakter word geskep deur positiewe persoons-, situasieen handelingsbeskrywing, koalisievorming en slagofferskap. Die afstand word vergroot deur negatiewe persoons-, situasie- en handelingsbeskrywing, asook deur gekleurde visie (Van den Bergh, 1981:163-164). Persoons-, situasie- en handelingsbeskrywing gaan dikwels hand aan hand. 
- Persoonsbeskrywing (die eienskappe waarmee 'n karakter toegerus word en die wyse waarop dit meegedeel word) kan die leser se respons ten opsigte van 'n karakter rig en sodoende ook manipuleer. Lesers identifiseer graag met positiewe karakters dus karakters met aantreklike eienskappe (Card, 1988:77-92). Onaantreklike, sentrale karakters dra by tot distansiëring (Wyndham, 1972:34; Stephens, 1992:260). Volgens Woolley $(1990: 60)$ kan 'n eensydige goeie of aantreklike karakter wat té perfek, goed, slim of mooi is, die leser ontoereikend laat voel. Karakters in kinderverhale beskik gewoonlik oor aantreklike eienskappe. Deur simpatie vir 'n onaantreklike of onaanvaarbare karakter te skep, kan 'n begrip vir die "ander" verkry word, soos byvoorbeeld met die gewigsprobleem van Manual (Wegloopwinter, Rona Rupert). Dié metode sal beter slaag indien 'n leser nie terstond met die negatiewe sy van 'n karakter gekonfronteer word nie, maar eerder met 'n eienskap waarmee die leser self kan empatiseer of identifiseer.

- Situasiebeskrywing (die ruimte en omstandighede waarin 'n karakter geplaas word) kan 'n bepaalde beeld en stemming ten opsigte van 'n karakter oproep en versterk. Hier is die fisiese omgewing sowel as die konteks ter sake. 'n Natuurbewaringsomgewing skep byvoorbeeld 'n positiewe beeld van die karakter, terwyl 'n karakter wat in 'n moeilike of onbenydenswaardige situasie verkeer, simpatie wek en lesersbetrokkenheid aanmoedig. Vaselinetjie (Anoeschka von Meck), waar die hoofkarakter haarself in 'n kinderhuis bevind, kan as voorbeeld dien.

- Handelingsbeskrywing hou verband met die karakter se eienskappe en omstandighede. Lesers verkies karakters wat 'n duidelike doel voor oë het, en nie bloot op gebeure reageer nie (Wyndham, 1972:35). Benewens die eienskappe waarmee karakters toegerus word, bepaal die gebeure in die verhaal hoe die leser teenoor die karakter sal voel. Lyding, opoffering, dreigende gevaar, seksuele spanning, tekens en voorbodes dra by tot betrokkenheid by die karakter en besorgdheid oor die uitkoms uit hul situasie (Card, 1988:68-74). Indien die leser die behoeftes, begeertes en drome van die karakter(s) verstaan, dra dit by tot 'n begrip vir die karakter en bevorder dit identifiseringsmoontlikhede (vgl. die karakter Slym in Slym: die eerste wurm in 'n paddakonsert (Fanie Viljoen) wat as wurm-outsider deur die paddas aanvaar wil word).

- Slagofferskap behels dat die karakter swak of afhanklik geteken word. Dit wek medelye en simpatie en verklein die afstand tussen 
leser en karakter (Van den Bergh, 1981:163). Bedreiging (fisies en psigies) dra by tot spanning en tot simpatie met die karakter. Vanselfsprekend sal die mate waarin die leser spanning beleef ook van die leser se lees- en lewenservaring afhang (vgl. Die lelike eendjie, Andersen).

- Gekleurde visie is volgens Van den Bergh (1981:163) 'n tegniek waarmee die afstand vergroot word. Hier word die leser beïnvloed deurdat 'n karakter 'n groep verteenwoordig wat nie ernstig opgeneem word nie. Hierdie tegniek kan waarskynlik ook tot ' $n$ positiewe beeld van 'n karakter lei deur assosiasie met 'n positiewe groep.

- Koalisievorming vind plaas wanneer 'n betroubare karakter 'n positiewe opmerking oor 'n karakter maak. Dit kan tot 'n positiewe karakterbeeld bydra (Van den Bergh, 1981:163). 'n Negatiewe opmerking deur 'n betroubare karakter kan waarskynlik die teenoorgestelde tot gevolg hê.

Bal (1986:100) onderskei die held van ander karakters deur kwalifikasie (verskaffing van uitgebreide inligting oor die karakter); verspreiding (die karakter kom dikwels en op belangrike momente in die verhaal voor); selfstandigheid (die held kan alleen voorkom en monoloë voer); funksie (belangrike handelinge word deur die held volvoer); en verhoudings (betrekkings word met die grootste aantal medekarakters onderhou). Dié onderskeidings hou onder meer verband met die struktuur van die werk, en dra ook by tot die held se bekendheid en belangrikheid. Die leser word op dié manier aangemoedig om met sodanige karakter te identifiseer. Vergelyk hier Woolley (1990:41) wat aandui dat identifisering aangemoedig word indien die sentrale karakter reeds vroeg in die verhaal bekend gestel word, op verskeie wyses by die handeling en belangrikste gebeure betrokke raak en ook by die ontknoping, optree. Deur die ouderdom of lewensfase van 'n karakter vroeg reeds te openbaar, word 'n karakter meer konkreet voorgestel en word identifisering bevorder (Wyndham, 1972:39).

Karakterhiërargie bepaal in 'n hoë mate die omvang en intensiteit van identifisering. Indien 'n verhaal om een karakter sentreer - soos dikwels in kinder- en jeugverhale die geval is - is dit byna vanselfsprekend dat die leser met dié karakter sal identifiseer. Dit is egter nie onwaarskynlik dat 'n leser ook terselfdertyd met ander, minder belangrike karakters kan empatiseer nie. Die aard van die identifisering kan telkens wissel - byvoorbeeld bewonderende identifisering met een karakter en simpatieke identifisering met ' $n$ ander. 


\subsection{Vertelproses}

\subsubsection{Perspektief}

Die verhouding wat deur die vertelstrategie en perspektief tussen leser en teks opgebou word, kan identifiseringsmoontlikhede skep of die indruk van afstand bewerkstellig (Ghesquiere, 1982:130). Die personale perspektief figureer prominent in kinder- en jeugverhale en is by uitstek ' $n$ manier waarop lesers aangemoedig word om met 'n bepaalde karakter te identifiseer. ' $n$ Variasie hiervan is die ekverteller wat veral in realistiese jeugverhale gebruik word. In hierdie perspektief word die leser in 'n subjekposisie geplaas en beskou die wêreld deur die oë van die ek-verteller of fokaliserende karakter (Talbot, 1995:31; Stephens, 1992:86,124). Dié perspektief leen hom goed tot die skep van 'n vertrouensverhouding tussen die betrokke karakter en die implisiete leser, met die gevolglike aanmoediging van identifisering.

Benewens die gekose perspektief, beïnvloed die konstantheid daarvan ook identifisering. Die gebruik van 'n enkele interne fokalisator dra by tot identifisering (Van Luxemburg et al., 1987:167; Bal, 1986:110; Card, 1988:163; Swain, 1990:17). Wisseling van fokalisator verswak die identifiseringsmoontlikhede (Stephens, 1992:260) en kan neutraliteit tot gevolg hê (Van Luxemburg et al., 1987:177). 'n Groot verskeidenheid karakters, elk met 'n eie stel motiverings wat om die leser se aandag meeding, kan identifisering bemoeilik omdat 'n fokuspunt ontbreek en die leser nie weet wie se belange vir hom die swaarste moet weeg nie. Doughty (2002:359) toon aan dat jong lesers tot 'n groter mate met die karakters in moderne herskrywings van volksverhale empatiseer. Hy skryf dit daaraan toe dat skrywers karakters meer realisties en relevant vir die leser maak, deur onder andere van 'n beperkte, enger perspektief van die fokaliserende karakter of ek-verteller gebruik te maak.

Die ekstradiëgetiese verteller het in 'n hoë mate in onguns geraak in kinder- en jeugverhale. Dit is egter 'n perspektief wat die moontlikheid aan die leser bied om met 'n groter verskeidenheid karakters te identifiseer. Verhale waarin groepe as karakters optree maak dikwels van hierdie vertelwyse gebruik. Dit sal waarskynlik gevind word dat lesers in hierdie tekste met verskillende gunstelingkarakters identifiseer. Vermoedelik sal die eienskappe van 'n karakter en sy rol in die storiegebeure die deurslag gee en nie die perspektief nie. 


\subsubsection{Verteltegnieke}

Om 'n karakter van binne te ken, bevorder identifisering (Booth, 1961:248; Ghesquiere, 1982:166). Tegnieke waardeur 'n karakter van binne geleer ken word (gedagte- en gevoelslewe), is benewens die perspektief, ook verteltegnieke soos selfopenbaring, die vrye indirekte rede en bewussynstroomtegniek. Die gebruik van briewe, dagboekfragmente en die kwasi-onthullende karakter van die ekvorm kan tot sterker identifisering bydra (Booth, 1961:282). Hierdie is 'n tegniek wat dikwels in realistiese jeugboeke gebruik word, soos byvoorbeeld in !Sit oom Paul (De Waal Venter) en Daar's vis in die punch (Jackie Nagtegaal).

Oor die mate waarin verteltegnieke wel identifisering beïnvloed, is daar nie eenstemmigheid nie. Ghesquiere (1982:165) is van mening dat identifisering die sterkste bevorder word deur die gebruik van die vrye indirekte rede. Hierteenoor vind Schram (1985:251) in sy navorsing dat narratiewe strukture slegs 'n geringe invloed op resepsie uitoefen en nie ' $n$ invloed het op die mate van betrokkenheid of afstand nie. Die gebruik daarvan lei wel daartoe dat die leser hom/haarself meer in die hoofkarakter herken en dié se lotgevalle wil meemaak.

Indirekte interne monoloog en alleenspraak kan van die leser verwag om in die bewussyn van 'n karakter te tree in wie hy of sy nie belangstel nie. Vir geslaagde identifisering moet daar eers aan die leser-karakter-verhouding gebou word, voordat te diep ín die karakter se bewussyn gedelf word (Macauley \& Lanning, 1964:94). Identifisering word nie slegs bevorder deur die karakter van binne te ken nie, maar ook deur sintuiglike ervarings te deel (Woolley, 1990:43). Betekenisvolle detail individualiseer die karakter en wek die nodige gevoelens teenoor hom op (Swain, 1990:128).

In afdeling 3 is aangetoon dat die aard van die teks as geheel bydra tot die aard en omvang van leserbetrokkenheid. Die estetiese afstand tussen teks en leser bepaal hoe maklik of moeilik 'n verhaal gelees word (Schram, 1985:206), en gevolglik ook die afstand tussen karakters en lesers en die aard van identifisering (Nodelman, 1981:180; Schram, 1985:239 en Van Assche, 1989:63). Die tegnieke wat volgens Stephens (1992:70) distansiëring aanmoedig, ondersteun die uitgangspunt dat die aard van die teks die afstand tussen leser en teks beïnvloed. Hierdie tegnieke sluit literêre kunsgrepe in soos wisseling van fokalisator, verskeie interpretasiemoontlikhede, metafisiese spel en selfbewuste tekstualiteit. 'n Teks wat aandag op sigself vestig, verg gewis ander vaardighede van 
lesers as dié waarin die klem op die storie en die karakter is (soos byvoorbeeld ' $n$ tradisionele reeksverhaal). Sodanige storieaspekte en -tegnieke verhinder volgens Dijkstra et al. (1994:141) die diëgetiese effek van die storie op die leser en die gevoel van sterk betrokkenheid by die fiksionele wêreld.

Storieaspekte of -tegnieke wat die leser se aandag aftrek en verhoed dat hy/sy in die fiksionele wêreld betrokke raak, kan geld vir die werk as geheel of slegs op 'n spesifieke plek in die storiegebeure van toepassing wees. Indien 'n skrywer byvoorbeeld in 'n sekere gedeelte van die storie spanning by die leser wil skep, behoort dié deel nie gekompliseer te word deur onwaarskynlikhede, statiese beskrywings of literêre tegnieke nie (Dijkstra et al., 1994:143-144).

Volgens Van Assche (1989:63) beteken dit nie dat die leser nie met karakters in 'n meer literêre werk sal identifiseer nie, maar slegs dat die aard van die identifisering waarskynlik sal verskil. Nodelman (1981:180) wys daarop dat kinder- en jeugliteratuur wat deur volwassenes hoog aangeskryf word, gewoonlik 'n mate van afstand tussen karakters en lesers plaas, en dikwels nie die gewildste keuse van die meerderheid jeugdiges is nie. Die skrywer moet dus self oordeel wat hy/sy met die spesifieke teks beoog, wie die leser is wat hy/sy in gedagte het, en op watter wyse die leser betrokke moet wees.

\section{Ten slotte}

Identifisering met karakters blyk 'n natuurlike deel van jong lesers se leeservaring te wees. Die aard van die leserbetrokkenheid verskil egter na gelang van die ontwikkelingsfase, die individu en die leesomstandighede. Kennis van die werking van leseridentifisering met karakters, en begrip vir die verskillende uitgangspunte hieroor kan help om die behoeftes en verwagtings van die leser beter te verstaan.

Die skrywer kan die estetiese afstand (identifisering of distansiëring) tussen leser en karakter beïnvloed. Deur die keuse van karakters gee die skrywer reeds blyke van die leser wat hy/sy in gedagte gehad het - so word identifiseringsmoontlikhede geskep. Die eienskappe waarmee 'n karakter toegerus word, asook sy/haar rol in die verhaalgebeure, kan die estetiese afstand verder bepaal. Die keuse en aanwending van vertelstrategieë rig grootliks die aard en omvang van leseridentifisering. Hierdie effek kan versterk word met behulp van verteltegnieke waardeur toegang tot die karakter se gedagte- en 
gevoelslewe verkry word. Die reëlmaat en aard van die verskyning van die karakter, asook die karakterhiërargie dra verder by tot die belangrikheid van 'n karakter in die leser se oë.

Die skrywer se vermoë om hom- of haarself met die jong karakter te vereenselwig, word dikwels as 'n voorvereiste vir suksesvolle karakterbeelding in kinder- of jeugliteratuur gestel. Hierdie betrokkenheid van 'n skrywer by die karakters wat hy skep, toon 'n sterk ooreenkoms met die identifiseringsproses.

The sympathetic rapport between the writer and his character should be so great that to all intents and purposes he becomes that character. He can then think, feel, see, smell, touch, and react to everything that affects that character as if it were all happening to himself (Wyndham, 1972:72).

Waarskynlik is 'n tegniek soos hierdie een van die natuurlike wyses waarop skrywers 'n aangevoelde behoefte aan leseridentifisering met karakters hanteer. Hierdie artikel illustreer dat begrip vir die verskynsel van leseridentifisering met karakters ook bewustelik bekom kan word, en toepassingsmoontlikhede vir die skryfteorie en -praktyk het.

\section{Geraadpleegde bronne}

AIKEN, J. 1982. The way to write for children. New York: St. Martin's Press.

ANDRINGA, E. 2004. The interface between fiction and life: patterns of identification in reading autobiographies. Poetics Today, 25(2):205-240, Summer.

APPLEBEE, A.N. 1978. The child's concept of story: ages two to seventeen. Chicago: University of Chicago Press.

BAL, M. 1986. De theorie van vertellen en verhalen: inleiding in de narratologie. Muiderberg: Dick Coutinho.

BEACH, R. \& BRUNETTI, G. 1976. Differences between high school and university students in their conceptions of literary characters. Research in the Teaching of English, 10(3):259-268, Winter.

BEACH, R. \& WENDLER, L. 1987. Developmental differences in response to a story. Research in the Teaching of English, 21(3):286-298, Oct.

BOOTH, W.C. 1961. The rhetoric of fiction. Chicago: University of Chicago Press.

CARD, O.S. 1988. Characters and viewpoint. Cincinnati: Writer's Digest Books.

CHAMBERS, A. 1991. The reading environment: how adults help children enjoy books. Glos: The Thimble Press.

CHORUS, M. 1991. De leeswereld van kinderen: een beschrijving van het leesproces bij kinderen uit de bovenbouw van de bassischool aan de hand van boekbesprekingen in de klas. Den Haag: Nederlands Bibliotheek en Lektuur Centrum.

COPLAN, A. 2004. Empathic engagement with narrative fictions. The Journal of Aesthetics and Art Criticism, 62(2):141-152, Spring. 
CULP, M.B. 1985. Literature's influence on young adult attitudes, values, and behavior, 1975 and 1985. English Journal, 74(8):31-35, Dec.

DE BEER, J. 1991. The appeal of the formula children's fiction series: there is more than meets the adult eye. Cape Librarian, 35(4):6-8, Apr.

DIJKSTRA, K., ZWAAN, R.A., GRAESSER, A.C. \& MAGLIANO, J.P. 1994. Character and reader emotions in literary texts. Poetics, 23:139-157.

DILLON, G.L. 1982. Styles of reading. Poetics Today, 3(2):77-88.

DONELSON, K. \& NILSON, A.P. 1989. Literature for today's young adults. 3rd ed. Glenview: Scott, Foresman.

DOUGHTY, A.A. 2002. "This is the real story ... I was framed": point of view and modern revisions of folktales. Journal of American \& Comparative Cultures, 25 (3/4):357-362, Fall.

EMERY, D.W. \& MILHALEVICH, C. 1992. Directed discussion of character perspectives. Reading Research and Instruction, 31(4):51-59, Summer.

GHESQUIERE, R. 1982. Het verschijnsel jeugdliteratuur. Leuven: Acco.

GREYLING, S.F. 1999. Die keuse, skep en voorstelling van karakters in verhale vir 11-14 -jariges. Potchefstroom: PU vir CHO. (Ph.D.-proefskrif.)

HANCOCK, M. R. 1993. Character journals: initiating involvement and identification through literature. Journal of Reading, 37(1):42-35, Sept.

HARDING, D.W. 1977. Psychological processes in the reading of fiction. (In Meek, M., Warlow, A. \& Barton, G., eds. The cool web: the pattern of children's reading. London: The Bodley Head. p. 58-72.)

HYNDS, S.D. 1985. Interpersonal cognitive complexity and the literary response processes of adolescent readers. Research in the Teaching of English, 19(4):386-402, Dec.

JAUSS, H.R. 1977. Ästhetische Erfahrung und literarische Hermeneutik 1. München: Wilhelm Fink.

JOSE, P.E. 1989. The role of gender and gender role similarity in readers' identification with story characters. Sex Roles, 21(9/10):697-713.

JOSE, P.E. \& BREWER, W.F. 1984. Development of story liking: character identification, suspence, and outcome resolution. Developmental Psychology, 20(5):911-924.

KINGSTON, A.J. \& WHITE, W.F. 1967. The relationship of readers' self concepts and personality components to semantic meanings perceived in the protagonist of a reading selection. Reading Research Quarterly; 11(3):101-116, Spring.

LOHANN, C. 1986. Kinderlektuur. Pretoria: HAUM.

MACAULEY, R. \& LANNING, G. 1964. Technique in fiction. New York: Harper \& Row.

MCGILLIS, R. 1996. The nimble reader: literary theory and children's literature. New York: Twayne.

NODELMAN, P. 1981. How typical children read typical books. Children's Literature in Education, 12(4):177-185.

PROTHEROUGH, R. 1983a. Developing response to fiction. Milton Keynes: Open University Press.

PROTHEROUGH, R. 1983b. How children judge stories. Children's Literature in Education, 14(1):3-13.

SCHRAM, D.H. 1985. Norm en normdoorbreking. Amsterdam: VU Uitgeverij. (Proefschrift: doctor in de letteren.)

SHANTZ, C.U. 1975. Empathy in relation to social cognitive development. Counseling Psychologist, 5(2):18-21. 
STEENBERG, E. 1988. Primêre behoeftes van tieners waarin hulle boeke voorsien. (In Cilliers, I., red. Op weg na begrip. Kaapstad: Maskew MillerLongman. p. 167-172.)

STEPHENS, J. 1992. Language and ideology in children's fiction. London: Longman.

SWAIN, D.V. 1990. Creating characters. Cincinnati: Writer's Digest Books.

TALBOT, M.M. 1995. Fictions at work: language and social practice in fiction. London: Longman.

TUCKER, N. 1981. The child and the book: a psychological and literary exploration. Cambridge: Cambridge University Press.

VAN ASSCHE, A. 1989. Karakters en personages in de literatuurdidactiek. (In Van Assche, A., red. Karakter en personages in de literatuur. Leuven: Acco. p. 61-75.)

VAN DEN BERGH, H. 1981. De verteller als strateeg: persuasieve processen in het korte verhaal. (In Segers, R.T., red. Lezen en laten lezen: recent receptie-onderzoek in Nederland en België. 's-Gravenhage: Nijhoff. p. 154-172.)

VAN DER WESTHUIZEN, E.S. 1997. Die representasie van die visie in die verhalende prosa van Elsabé Steenberg. Potchefstroom: PU vir $\mathrm{CHO}$. (Ph.D.-proefskrif.)

VAN LUXEMBURG, J., BAL, M. \& WESTSTEIJN, W. 1987. Over literatuur. Muiderberg: Dick Coutinho.

WHITEHEAD, F., CAPEY, A.C., MADDREN, W. \& WELLINGS, A. 1978. Children and their books. Hampshire: Macmillan Education. (Schools Council Research Studies.)

WOOLLEY, C. 1990. Writing for children. New York: NAL Books.

WYNDHAM, L. 1972. Writing for children and teenagers. 2nd ed. Cincinnati: Writer's Digest.

\section{Kernbegrippe:}

identifisering

jeugliteratuur

karakter

kinder- en jeugliteratuur

kinderliteratuur

leser

Key concepts:

character

childrens' literature

creative writing

identification

reader

youth literature 